in the number of the staminal whorls. Calyx and corolla present the normal condition, while the stamens have taken the shape of petals. Though the ten stamens belong to two whorls, the petalodes are more or less connate at the base into ro-merous whorls; but the petalodes of all the whorls are in superposition, showing thus that they must be considered as consisting of alternate 5-merous whorls, and this is also apparent by the aestivation of the broader petalodes of the outer whorls; the first five petalodes, of course, are opposite to the corolla lobes, as the ericaceous flower is obdiplostemonous. The number of ro-merous whorls in each flower is about ten; the shape of the petalodes changes from the broadly oval of the outer ones to the oblong shape of the innermost petalodes. Even the carpels are changed into narrow oblong petalodes. Only in one case I found an incompletely developed anther adhering to one of the petalodes.

As it would be interesting to have this shrub in cultivation, though the horticultural value of this form is lessened by the rather difficult cultivation of the species, we sent rooted suckers to the Arnold Arboretum, but the plants did not survive, and concerning the fate of a few sent to a German nursery I know nothing. The old plant, however, is in all probability still there, and we may yet hope to see this handsome form introduced into cultivation. Dried specimens of it are preserved in the herbarium of the Arnold Arboretum.-Alfred Rehder, Arnold Arboretum.

\title{
PUCCINIA UPON MELOTHRIA
}

\section{(WITH ONE FIGURE)}

This rust was found in the neighborhood of West Raleigh, N. C., in the autumn of I907 upon Melothria pendula. The host is not a common plant in this locality, only two plants being seen during an entire collecting season; one of these was thoroughly infected, the other not at all.

The species is of special interest on account of the comparative paucity of rusts affecting the cucurbits, as well as owing to the economic importance of this family. On the whole family as represented by the North American genera, either native or exotic, listed in SMALL's Flora of the South Eastern United States, Gray's Manual, Gray's Field, Forest, and Garden Botany, and BRITTON and BRown's Illustrated Flora, there are mentioned in FARLOW's Host Index no rusts at all. In SACCARDo there are six species, as follows: (I) Uromyces Melothriae on M. tomentosa in Abysinia; (2) $U$. Cayaponiae on C. racemosa in Africa; (3) U. Hellarianus on Cayaponia in Porto Rico; (4) Puccinia Cucumeris on C. ficifolia in Abyssinia; (5) P. 
Momordicae on $M$. cordifolia in Natal

(6) Aecidium Momordicae on Momordica in Brazil.

The Puccinia upon Melothria pendula is different in shape, color, and size of spores from $P$. Cucumeris and from $P$. Momordicae, and seems clearly to be an undescribed species. The germination of the teleuto-spores occurs freely in the older sori, placing the rust among the Leptopucciniae. The following description is proposed.

Puccinia Melothriae, n. sp. - III. Teleutosori: hypophyllous, crowded in irregular concentric circles, pustular, soon naked, pulverulent, cinnamon-colored (no. 32 Sacc.), cinereous on germination, ruptured epidermis inconspicuous; spots pale, indefinite. Teleutospores: hyaline to straw-colored (no. 26 Sacc.), $40-5^{2} \times$ ıо-ı6 $\mu$; slightly or not at all thickened at apex, often not constricted at septum, wall about $2 \mu$ thick, smooth. Terminal
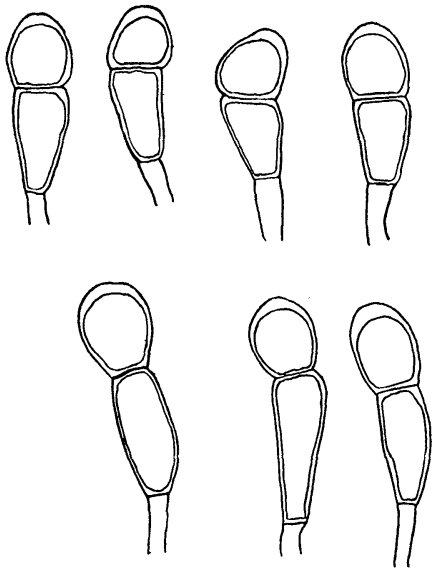

Puccinia Melothriae, n. sp. cell usually round, rarely oblong, I0-I $6 \times 12-20 \mu$. Basal cell wedgeshaped, IO-I $5 \times 20-30 \mu$. Pedicil $20-45 \mu$ long, hyaline. Germination immediate; that of the terminal cell by an apical promycelium, that of the basal cell by a lateral promycelium.

On Melothria pendula L., West Raleigh, N. C., 9-15-06, F. L. Stevens and J. G. Hall, type no. 47I.-F. L. Stevens, West Raleigh, N.C.

\section{AN INSTANCE OF MUTATION}

Euphorbia marginata Pursh, commonly called in Colorado "snow-onthe-mountain," is easily recognized by its white-margined upper leaves or bracts, and the five white appendages of the floral glands. In the splitting up of the old genus Euphorbia, it has been referred to a genus Dichrophyllum Kl. \& Garcke, and distinguished from Tithymalus Adans by the characters just mentioned. In Tithymalus there are but four glands, with rudiments of the fifth. All authors seem to agree that $E$. marginala has five glands; "three" in BRITTON and BRown, Ill. Flora 2:376, is a mere misprint, as the figure shows. Having recently had occasion to examine E. marginata at Boulder, Colorado, I have been astonished to find that four glands is normal in this locality, and a plant with five glands 